\title{
AN APPRAISAL OF THE LEGAL FRAMEWORK FOR MERGERS AND
}

\section{ACQUISITIONS IN NIGERIA}

\section{ADEKE AONDONGU ABEL ESQ}

Associate, S. M ALSO \& CO, Opposite Government House, Damaturu, Yobe State-Nigeria

ABSTRACT
Companies and agencies have found way of bailing themselves out of serious financial distress or build for
themselves stronger business entities, through the use of mergers and acquisitions as an effective corporate restructuring
tool. Most companies in Nigeria used mergers and acquisitions as a strategy to wither the storm of economic recession
that bedeviled the Nation's economy or meet up with the regulatory requirement for the purpose of recapitalization.
Several sectors of the economy ranging from banking, oil and gas, insurance, health care, telecommunications and the
Fast Consumer Moving Goods (FCMG) have all actively witnessed mergers and acquisitions transactions.
KEYWORDS: Merger, Acquisitions, Economy \& Competition

Received: Jul 14, 2017; Accepted: Aug 04, 2017; Published: Nov 09, 2017; Paper Id.: IJAFMRDEC20173

\section{INTRODUCTION}

The concept of mergers and acquisitions has become a pivotal tool for economic growth and development in today's commercial world. The concept is largely used for restructuring business entities. ${ }^{1}$ Mergers and acquisitions are, nowadays, frequent events in the life of cycles of companies, on the basis that mergers and acquisitions are one of the successful means of enabling companies and economic entities achieve profits, whether through entry to new markets, taking advantage of economies of scale or reducing costs associated with producing a greater number of products and services. ${ }^{2}$

Recently, following the failure of Etisalat Nigeria to restructure its loans amounting to Five Hundred and Fourty One Billion Naira (N541, 000,000,000.00), the telecom giant announced a share restructuring which will see thirteen commercial banks acquire control of the company shares through their legal representatives Capital Trust Limited. ${ }^{3}$ Various factors suggest there will be improvement in mergers and acquisitions deal inflow in terms of value and numbers in 2017 , as measures to address forex liquidity challenges are implemented and the resilient market adopts long term strategies and alternative capital structures to address the economic challenges. Mergers and Acquisitions in specific sectors maybe spurred by legal and regulatory policies targeting struggling businesses in certain sectors, transactions like that have the tendencies that could give birth to more efficient corporations springing from ongoing mergers, consolidations and restructuring initiatives targeted at saving

\footnotetext{
1. Abubakar, G. Abubakar B. M and Umar M. S (2014) "Procedural Issues in Mergers and Acquisitions of Companies: A Comparison between Nigeria and India", European Journal of Business and Management Vol. 6, No. 8, at P. 111 Available at http://www.iiste.org/journals/index.php/EJBM/article/view/11542pdf visited 21/06/2017

${ }^{2}$ Ibid

3 Available at https://www.dailytrust.com.ng/news/business/13banks-takeover-etisalat-nigeria/202589.html visited $21 / 06 / 2017$
} 
struggling business entities. ${ }^{4}$

Therefore, mergers and acquisitions happen to be a key component of today's commercial activities that have contributed greatly towards the expansion of several businesses thus playing a vital role in the economic development of any nation. It is as a result of the impact mergers and acquisitions have on the economic development of several countries that has necessitated it adoption by many nations who have further strengthened the concept by including same into their various laws of which Nigeria is not an exception. ${ }^{5}$

In light of the foregoing, this paper will appraise the conceptual and legal framework for mergers and acquisitions in Nigeria, examine the impact of mergers and acquisitions on the Nigerian economy, as well as make findings and proffer suggestions on the way forward among other issues.

\section{MEANING OF MERGERS AND ACQUISITIONS}

Mergers and acquisitions is still an emerging area in the academic parlance in Nigeria. This is not surprising owing to the fact that Nigeria's economy is still evolving. These notwithstanding several scholars have in one way or the other attempted definition of mergers and acquisitions. An author, Ogbuanya, defines mergers as:

A business combination which involves the fusion of two or more corporate entities into one, largely on equal terms, is often refers to as mergers. An acquisition on the other hand is essentially the purchase by one company of all or substantial interest of another company, such that the acquired company becomes a subsidiary or division of the acquiring company. ${ }^{6}$

Bhadmus, on his part adopted the statutory definition of mergers provided under the Securities and Investment Act (2007), wherein merger means "any amalgamation of the undertakings or any part of the undertakings or interest of two or more companies or the undertakings or the part of the undertakings of one or more companies and one or more bodies corporate. ${ }^{, 7}$ For Coates:

Mergers and acquisitions characteristically, involve a purchaser or buyer and seller. The business been transferred is called the "target", which may be separately incorporated, or may consist of an operating unit or division. In some merger and acquisition transactions, there is no clear purchaser or seller. Two companies combined their assets in what is called merger. ${ }^{8}$

For Idigbe, mergers and acquisitions are characteristics of today's entities, saddled with the task of strengthening many businesses thus helping in the economic advancement of any nation. Another author Amupitan:

Mergers and acquisitions became a popular scenario during the last banking recapitalization in Nigeria. It is also used as a managerial discipline which seeks to remove managers of underperforming enterprises and replace them with a

\footnotetext{
${ }^{4}$ Adebowale F. E and Eze O. C (2017), “2017 Mergers and Acquisitions Reports: Nigeria”, International Financial LawReview, available at http://www.iflr.com/article/3673251/2017-mergers-and-acquisition-report-nigeria.html visited 22/06/2017.

${ }^{5}$ Idigbe, T. "Mergers andTakeover Procedure under ISA 2007” at P. 1 available at www.nigerianlawguru.com>articlespdf visited 21/06/2017

${ }^{6}$ Ogbuanya, N. C. S, (2014) “Essentials of Corporate Law and Practice in Nigeria”, Novena Publishers Limited (2 ${ }^{\text {nd }}$ ed) at P. 587

${ }^{7}$ Bhadmus, H. Y (2013) “Bhadmus on Corporate Law Practice”, Chenglo Limited, Lagos ( $3^{\text {rd }}$ ed)

${ }^{8}$ Coates, J. C (2014)" Mergers, Acquisitions and Restructuring”, Publish by European Corporate Governance Institute at P. 3 available at http://ssrn.com/abstract_id=2463251pdf visited 22/06/2017
} 
more vibrant management through sales of control of the company's shares to a willing buyer. The new buyer acquires controlling shares and is free to bring in his own managers... 9

For Oloye and Osuma the term "mergers" and "acquisitions" are often used interchangeably to mean the same thing, and in a more common sense used in the dual form as "mergers and acquisitions" which is (abbreviated M \& A). ${ }^{10}$ For Abubakar, Abubakar and Umar:

The concept "mergers" and "acquisition" are most times interwoven, and in a general parlance used in the Siamese pattern of mergers and acquisitions. Acquisition means the process of taking total control over the substantial assets or management and interest of another corporation. ${ }^{11}$

Flowing from the above definitions, it is agreed that mergers and acquisitions is one of the major forms of corporate restructuring measures adopted by business organizations and corporations to survive economic challenges or build stronger business entities.

\section{BRIEF HISTORICAL OVERVIEW OF MERGERS AND ACQUISITIONS IN NIGERIA}

In Nigeria, there were no successful mergers and acquisitions in the real sector of the economy until 1983 to 1996. Even then, the impact was not felt. Only few foreign firms in Nigeria merged in this period. Between 2004 and 2005 , the wave of mergers and acquisitions was high though mainly in the banking sector. ${ }^{12}$

The first successful merger in Nigeria was that between A. G Leventis \& Company limited and Leventis Stores Limited in 1983, but the most celebrated merger was between Lever Brothers Nigeria Limited - a quoted company and Lipton Nigeria Limited - a private company. ${ }^{13}$ Historically, therefore, serious mergers and acquisitions in Nigeria began when the country's apex regulatory bank in a bid to stabilize the Nigerian financial institutions increased the capital ratio of banks doing business in Nigeria from Two Billion Naira to Twenty Five Billion Naira. And with a deadline of $31^{\text {st }}$ December, 2005; the apex regulatory bank went further to notify all banks that they could make use of corporate restructuring tools such as mergers and acquisitions for the purposes of meeting up with the compulsory requirement of Twenty Five Billion Naira to prevent winding up. ${ }^{14}$

The banking reform of 2005 was therefore the bird that flew the kite for real mergers and acquisitions in the Nigerian economy. It was during that era that Standard Trust Bank Limited merged with United Bank for Africa (UBA),

\footnotetext{
${ }^{9}$ Amupitan, J. O (Friday, 02/06/2017)" Nigerian Corporate Governance: From Concentrated Ownership to Dispersed Ownership - Which Way Forward”. At P. 64 - 65, 81 ${ }^{\text {st }}$ Inaugural Lecture of the University of Jos, delivered at the Multipurpose Auditorium, University of Jos

${ }^{10}$ Oloye, M. I and Osuma, G. (2015)" Impacts of Mergers and Acquisitions on the Performance of Nigerian Banks (A Case Study of Selected Banks)", Pyrex Journal of Business and Finance Management Research.at P. 3 available at http://www.pyrexjournals.org/pjbfmr.pdf visited 23/06/2017

${ }^{11}$ Abubakar, G. Aubakar B. M, and Umar, M. S opCit at p.113

${ }^{12}$ Udoidem, J. O and Acha, I. A, (2012)" Corporate Restructuring through Mergers and Acquisitions: Experience from Nigeria", Journal of Economic and Sustainable Development Vol. 3, No. 13 at P. 135 available at http://www.iiste.org/journals/index.php/JEDS/articles/view/3499/3523pdf visited 29/06/2017

${ }^{13}$ Oloye, M. I and Osuma, G. opCit at p.26

${ }^{14}$ Festus A. F and Adenike A. N (2010)" Mergers and Acquisitions in Nigeria: Imperatives of Global Integration" at P. 11 available at http://eprints.covenantuniversity.edu.ng/4214/1PUB\%252017.docandrct=i\&dsa=uandved=oahUKwiqgpHUOpuahxrl8AKHqxBK8qfgg-

MAQ8q=bankingsectormergersandacquisitionsinnigeria\&usg=AFQJCNHUXCCuunOLE66hazds4qwl4rhogpdf visited 29/06/20147
} 
Bank of the North together with consortium of other banks merged to form Unity Bank Plc. While other banks who could not embrace merger and acquisition such as Savannah Bank, Societe General Bank, All States Bank among others folded up.

Unfortunately, most of the Nigerian banks in operation at that period could not efficiently take advantage of the options of mergers and acquisition due to one reason or the other. As a result of this development 14 banks were liquidated while the remaining merged into 25 banks. ${ }^{15}$ This development drew the attention of other sectors on the economic importance of mergers and acquisitions which later gave birth to several other mergers and acquisitions in diverse sectors of the economy.

\section{FACTORS INFLUENCING MERGERS AND ACQUISITIONS}

There are some reasons for engaging in corporate restructuring exercises such as mergers and acquisitions, which have been considered to primarily add to shareholder's value. They are as follows:

- Economies of Scale: Economies of scale is achieved when cost is saved by businesses as a result of upsurge or increased production of goods and services economies can be maximized using mergers and acquisitions. ${ }^{16}$

- Operating Economies: In addition to economies of scale, a combination of two or more firms may result in cost reduction due to operating economies. A combined firm may avoid or reduce overlapping functions and facilities. It can consolidate its management functions such as: manufacturing, marketing, accounting, and reduce operating cost. Therefore operating economies can often be achieved through the combination of companies. ${ }^{17}$

- Synergy: with the coming together of more than one firm through mergers and acquisitions synergy is achieved owing to the fact that the combined asset of several firms is more profitable than the sum of one single firm. ${ }^{18}$

- Technology Transfer: Technology and other resources are being transferred especially through cross border merger and acquisition transactions thus creating value. ${ }^{19}$

- Management Efficiency: Companies with poor management will lead to low/poor productivity. Therefore the need for merger with other companies who have required technical know-how would be very important. ${ }^{20}$

- Foreign Direct Investment (FDI): The acquisition of a Nigerian entity is the preferred way for a foreign investor to gain entry into the Nigerian business market. This is due to the fact that an acquisition provides access to existing structures, possibly with any permit and assets in place. ${ }^{21}$

\footnotetext{
${ }^{15}$ Adebayo, O. and Olalekan O. (2012)" An Analysis of the Impact of Mergers and Acquisitions on Commercial Banks in Nigeria," Research Journal of Finance and Account Vol. 3 No. 7 at P. 91 available at http://www.iiste.org/journal/index.php/RJFA/article/viewfile/2638/2653\&rct=j\&sa=u\&ved=oahukewjpmcgjuexuahxeb8a khbesbzcafggomam\&q=bankthatsurvivedmergersin2006\&usg=afajicngzi1sdoyvd9i6nnymba3|2bddltgpdf visited29/06/2017

${ }^{16}$ Oloye, M. I and Osuma, G. opCit at p.27

${ }^{17} \mathrm{Ibid}$

${ }^{18}$ Ibid

${ }^{19} \mathrm{Ibid}$

${ }^{20} \mathrm{Ibid}$

${ }^{21}$ Giwa, O. and Oluwole, O. (2013)" Mergers and Acquisitions in Nigeria; Current Issues" at P. 112 available at http://www.giwa-osagay.com/we-content/uploads/09/mergers-\&acquisitions-nigeria-
} 
- To increase market, share through merging with or buying out smaller rivals. A good example of this was the acquisition of Visafone by Mobile Telecommunications Network (MTN). ${ }^{22}$

- To avoid been push out of the market, this is the option that several banks (including foreign owned banks) took following the capitalization program in the banking and insurance industries ${ }^{23}$

\section{THRESH HOLDS AND CATEGORIES OF MERGERS AND ACQUISITIONS}

The Securities and Exchange Commission (SEC) has the power to prescribe a lower and an upper thresh hold of combined turnover or assets or a combination of both in Nigeria, in general or in relation to specific industries. For the purposes of determining categories of mergers by virtue of section 120 of ISA pending the time SEC prescribes a thresh hold, the lower is N500,000,000.00 while the upper thresh hold is N5,000,000,000.00. ${ }^{24}$

A small merger is that which is valued at N500, 000,000.00 or less. Under small merger restructuring procedures outlined by law, business concerns are not mandated to inform the key regulatory authority which is the Securities and Exchange Commission except the commission directs such merging entities to do so. Nevertheless, the commission is empowered to direct the merging entities to notify it within six months of implementation of the small merger if the commission foresees that the small merger will further promote monopolistic tendencies, hamper competition or is contrary to public interest. Once the Commission seeks to be notified status quo as it relates to the merger must be maintained for a period of 20 days or more within which the Commission is to notify parties as whether the merger is approved, disapproved, or subject to conditions and prohibition of the merger if it is yet to be implemented and if already implemented, a declaration that the merger is prohibited. ${ }^{25}$

Based on the foregoing, it can be inferred that although parties to a small merger need no notification to consummate their merger, the Commission may in furtherance to it powers under the Act direct the parties to notify it. ${ }^{26}$ Once the Commission express interest for it to be notified it becomes compulsory and not optional of which failure to comply could result in grave consequences or sanctions against such mergers by the Commission. The safest thing for parties to a small merger to therefore do is to obtain the necessary approval from the Commission and all relevant authorities, if the request for notification in respect of a small merger is made by the Commission.

The second category of merger is the intermediate merger. For a merger to be termed as an intermediate merger, it has to be above N500, 000,000.00 but not up to N5, 000,000,000.00 in value. Once the value of a merger falls within the categorization of an intermediate merger, the Securities and Exchange Commission as well as the registered trade unions or their representatives must as a matter of necessity be notified unlike in the case of a small merger where notification to the

2012.pdf\&rct=i\&sa=u\&ved=oahukewirvlhp-

ubuahvij8akhviciiqfgeemaa\&q=mergers\&acquisitionsinnigeriacurrentissues\&usg=afojcna02vumclrv02+qnz*vep-gvfuapdf visited 01/07/2017

22 Ibid

23 Ibid

${ }^{24}$ Bucknor, O (2015)" Mergers and Acquisitions in Nigeria: Law and Procedure", Acas\&Law at P.2 available at www.acaslaw.com>assets>acas-mergers\&acquisitionsinnigeria:lawandprocedure\&usg=AFQJCNFg8-oijw3zrykrp7A3RUNmiEg9zapdf visited 01/07/2017

${ }^{25}$ Section 122 (3), 4, 6 ISA

${ }^{26}$ Section 121 ISA 
commission is not compulsory unless required. ${ }^{27}$ Intermediate mergers are usually a bridge or interface between small and large mergers.

The third category of merger is the large merger which usually encompasses a merger transaction valued from N5, 000,000,000.00 and above. Upon the receipt of the notice of a large merger by the Securities and Exchange Commission, the Commission is obligated by law to refer such notice to the Federal High Court and upon the fulfillment of notification requirement within a period of at most 40 days, communicate with the Court its decision in respect of the large merger as to whether or not the merger is approved subject to any condition or prohibition. ${ }^{28}$ Unfortunately the Investment and Securities Act does not state if the notification of trade unions or their representatives is required under a large merger procedures. Notwithstanding this grave omission, public policy demands that registered trade unions or their representatives be notified of the large merger. ${ }^{29} \mathrm{~A}$ situation where the law makes provision for the notification of the registered trade union or their representatives in the case of an intermediate merger but omits to make similar provisions for big ticket transactions such as large mergers, leaves so much to be desired and has created a lacuna which needs to be addressed by our legislators in subsequent amendments since law making is a continuous process.

There has been resentment from some quarters that the provisions under section 123 to 126 of the ISA Act did not on the face, provide for application to court after the grant of approval by the Securities and Exchange Commission and so therefore, there is no legal basis for making such application to the Court. But those who feel application to court after the grant of approval is legitimate opined that the orders which parties may require in terms of section 122 (6) are generic to all kinds of transactions. According to a scholar who was privileged to be a privy to the development of the Investment and Securities Act (ISA), opined that the purpose of the legislators was to make application to court compulsory for large merger transactions but do away with same in respect to small and intermediate mergers thus reposing confidence in the Securities and Exchange Commission to efficiently handle small and intermediate mergers without the courts' interference. ${ }^{30}$ As valid as this argument may sound, one can safely argue that the duty of interpretation of statutes and the intention of the legislators is that of the court and not of scholars.

\section{IMPACT OF MERGERS AND ACQUISITIONS ON THE ECONOMY}

Mergers and acquisitions of companies is a global issue though largely common in industrialized countries. They are mechanisms for maximization of a company's share of the market, to enhance profitability and ultimately increase and secure the capital of the company and shareholders. ${ }^{31}$

Mergers and acquisitions have helped economies to adjust to major competitive changes, alternative management teams and organizational structures for control of corporate assets. These have enabled vast economic resources to their highest valued use. Mergers and acquisitions have become a ready tool in the hands of many for the purposes of shoring up their capital base to meet up with regulatory requirements in specific sectors, save ailing companies from folding up, diversification of the economy among others. ${ }^{32}$.

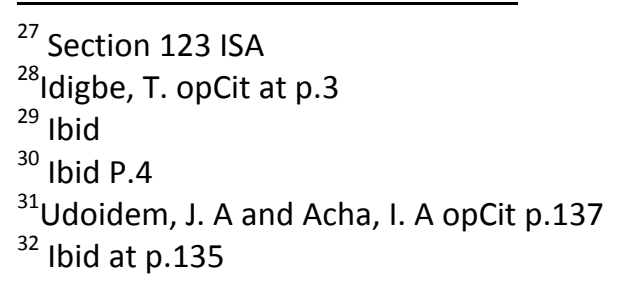


In addition, both developed and developing economies require new technologies for economic growth. Mergers and Acquisitions could lead to the speedy adoption and/or transfer of new technologies. Technological change is an economic good and is the driving force of long-term economic growth. Since mergers and acquisitions are instrumental to technological change, they serve as engines of growth in developed and developing economies like Nigeria through direct foreign investments. ${ }^{33}$

\section{WHY MERGERS AND ACQUISITIONS FAIL IN NIGERIA}

Just as it is common for most developing economies to encounter challenges with corporate restructuring processes such as mergers and acquisitions, Nigeria is also not an exception. Principal among these challenges are the emergence of anti-competition tendencies thereby creating monopolies and the desire of investors to exclusively cling unto their companies to avoid losing control among others. ${ }^{34}$

In light of the foregoing, the following are reasons why mergers and acquisitions fail in most countries, with Nigeria inclusive:

- Inadequate knowledge: Merging entities are unaware of the fact that just the way a promoter can set up the necessary machinery for the efficient take off of a company prior to when incorporation will be completed, companies intending to merge can put their house together pending when the necessary permits and approval will be obtained from the relevant regulatory authorities. Good preparation means the integration can kick off on day one. $^{35}$

- Lack of common vision: This is occasioned by the absence of a clear statement of what the merging company will stand for, how the organization will operate, what it will feel like, and what would be the difference. Compared to how things are today, there will be no point of convergence on the horizon and so the merging entities will never blend. $^{36}$

- Poor management team: Upon the consummation of a merger deal, there is always a conflict of interest as to who will be in charge of the affairs of the new merging entities that usually results to in fighting that sometimes degenerates into bringing the new merger to a standstill. ${ }^{37}$

- Poor information flow: Lack of proper information flow between the merging entities and their employees often causes panic among employees as to the fate of their work which in most cases leads to the resignation of some staff that could have been vital to the stabilization of the merging entities, upon the consummation of the merger agreement. ${ }^{38}$ This reason accounts for why most of us frown at the absence of notification to trade unions or their representatives in the case of large mergers in Nigeria under the Investment and Securities Act.

\footnotetext{
33 Ibid

${ }^{34}$ Omoye, S and Aniefor S. J (2016)" Mergers and Acquisitions: The trend in Business Environment in Nigeria," Accounting and Finance Research Vol. 5 No. 2 at P. 10 Published by Sciedu Press available at http://dx.doi.org/10.5430/afr.v5n2p10pdf visited 02/07/2017

${ }^{35}$ Scigenthaler, P. J (2010) "The most Common Causes for Companies failing to Integrate and Profit from Mergers and Acquisition activity" available at http://www.thetelegraph.co.uk/finance/businessclub/7924100/10-reason-mergers-\&acquisitions-fail.html visited 02/07/2017

${ }^{36}$ Ibid

37 Ibid

38 Ibid
} 
- Improper implementation: The inability of the merging entities to properly implement the merger plan as detailed out by the parties most times causes confusion and frustration that could result to the grounding of the company, if proper care and tolerance is not exercised. ${ }^{39}$

- Fear of the unknown: Lack of courage to take key decisions due to the fear of what the outcome of such decisions will be on the investors, consumers and even the employees, could bring the new entity to a standstill. ${ }^{40}$

- Poor leadership style: Most companies that have restructured are often faced with the challenge of getting managers who will pilot the affairs of the company for the purposes of turning the economic fortunes of the company around as well as directing the employees on the best way to follow. Failure to constitute a good management team often results in the crash of most firms even after they might have successfully merged. ${ }^{41}$

\section{OVERVIEW OF SOME RECENT MERGERS AND ACQUISITIONS IN NIGERIA FROM 2015 - 2016}

Despite the relative low mergers and acquisitions in Nigeria, 2016 still saw a number of transactions in various sectors of the Nigerian economy, some of which included Fast Moving Consumer Goods (FMCG), oil and gas, power, insurance, manufacturing and the banking sector to a lesser extent. Due to the recent trend of cross border transactions in mergers and acquisitions in Nigeria, a good number of the transactions that resulted into merger and acquisitions happened through foreign direct investments medium.

The Mergers and Acquisitions that occurred in the Fast Moving Consumer Goods, oil and gas, insurance, manufacturing and health sectors in Nigeria in 2015/2016 are as follows: ${ }^{42}$

- In the Fast Moving Consumer Goods (FMCG) SAB miller and Gutsche family investment merged with CocaCola company, $50 \%$ of Multi-pro Nigeria was acquired by Kellog company, Olam international limited acquired Bua mills limited and Bua pasta limited, Chi limited was acquired by Coca-Cola company.

- In the telecommunication sector Visafone which happens to be Nigeria's only surviving Code Division Multiple Access was acquired by Mobile Telecommunication Network (MTN)

- In the oil and gas sector, a major stake was acquired in OANDO which happens to be Nigeria's largest oil indigenous company by Helios and Netherlands.

- In the insurance sector, $25 \%$ stakes in Lead way insurance was acquired by Swiss Re-s

- In the health care industry, Hgeia group was acquired by IFC and Swiss Reconsortiums.

\section{LEGAL FRAMEWORK FOR MERGERS AND ACQUISITIONS IN NIGERIA}

The following are legislations that regulate mergers and acquisitions in Nigeria: ${ }^{43}$

- The Investment and Securities Act (ISA) 2007, and the Rules and Regulations of the Securities and Exchange

\footnotetext{
${ }^{39}$ Ibid

40 lbid

41 Ibid

${ }^{42}$ Available at https://www.globallegalinsites.com/practice-areas/mergers-\&-acquisition/global-legal-insites...mergers\&acquisitions-6th-ed-/nigeria\#chaptercontent7 visited 02/07/2017.

${ }^{43}$ G, Abubakar, Abubakar B. M, and Umar, M. S. opCit at p.111-112
} 
Commission (SEC) made pursuant to the ISA

- $\quad$ The Companies and Allied Matters Act (CAMA)

- $\quad$ The Banking and other Financial Institutions Act (BOFIA)

- The Insurance Act

- The Asset Management Corporation of Nigeria Act

- The Nigerian Electricity Regulatory Commission Act

- The Nigerian Communication Commission Act

The Investment and Securities Act 2007 and the Rules and Regulations of SEC made pursuant to the ISA: The major law regulating mergers and acquisitions in Nigeria in all sectors is the Investment and Securities Act (ISA) 2007 and the rules and regulations of SEC. ${ }^{44}$

The ISA 2007 is divided into XVIII (eighteen), all dealing with issues bordering on the capital markets while part XII of the Act specifically deals with the regulation of mergers and acquisitions by the Commission. ${ }^{45}$

The ISA 2007 has also tried to fill the vacuum created by absence of a comprehensive legal framework for regulation of competition in the Nigerian economy. It is expected that when the competition bill becomes law in Nigeria, the capabilities achieved by SEC will be transferred to the new Competition Commission. SEC through focus should in the long term be determining the fairness of merger transactions between the various shareholders. ${ }^{46}$

Prior to now, the procedure particularly with respect to mergers of public companies is to first obtain the commission approval in principle, then file an application to court to request for court ordered meeting to vote on scheme. In application to court, the approval in principle is exhibited and on the strength of the application, the court will order meetings of respective shareholders. After the court ordered meeting, SEC approval is also sort and obtained before approaching the court via a petition to sanction the merger in line with the resolutions passed at the court ordered meeting. This whole process is captured under section 100 of ISA 1999. In the nut shell, two approvals were required from the commission. That is, approval in principle and the main approval. ${ }^{47}$

The above vigorous practice appeared to have been dispensed with in the ISA 2007. This is in line with the legislative intent to reduce transaction cost and create certainty both from an advisory and from a business point of view. The intent as captured under ISA 2007 is to interface with SEC once through making notification and seeking only one approval from the commission. This applies to all categories of mergers. ${ }^{48}$

Again, expensive advertisement of court ordered meetings maybe saved by the new procedures except SEC decides to insist on advert before meeting to approve merger resolutions. ${ }^{49}$ Investment and Security Act 2007 also contains 
a provision which extends the merger controlled jurisdiction to not only companies, but also to businesses organized in the form of partnership. Specifically, Section 118 (2) ISA 2007 provides that "the provisions of this parts XII shall apply to partnerships". This particular innovation amongst others has rankled and amazed many participants in the capital markets. $^{50}$

It is respectfully agreed however, that the inclusion of the provisions should rather be commended than criticized as it is what has been operational in other developed part of the globe such as America and the United Kingdom, in line with international best practices and Nigeria should not be left out. ${ }^{51}$ The extension of merger control to partnerships is thus a welcome development and a further expansion of our legal jurisprudence and frontiers of the law which is quite similar to what is obtained in UK which has a similar legal system with that of Nigeria.

The ISA 2007 has noted the importance of trade unions or their representatives in a merger process and thus included them in the merger process in the case of an intermediate merger. ${ }^{52} \mathrm{We}$ are hopeful that such privileges will be extended to trade unions in the case of large mergers and even small mergers in future legislations. The commission is further empowered to order the breakup of companies who venture into a merger for the purposes of preventing or lessening competition in a particular business sector. ${ }^{53}$

The ISA 2007 Act also provide for three tests under which mergers are to be substantively accessed. These three tests are both sequential and alternatives, which are the test of "technological efficiency or precompetitive gain greater than the harm to competition, the test of substantially lessening or prevention of competition and the test of justification on substantial public interest grounds." The latter word allows considerations such as the effect of the merger on employment, particularly industrial sector, and the ability of national industries to compete in international market. The Securities and Exchange Commission usually considers whether the consummation of a particular merger will lead to the elimination of a business rival or competition in determining whether a merger is likely to substantially prevent or lessen competition. ${ }^{54}$

It will however, be premature at this stage to say that we have arrived so to say with the ISA 2007. This is because the act is still undergoing several testing phases and some criticisms have come up in its daily implementation. Having stated this, one thing is sure and that is the fact that we have an improved Act that seeks to address concerns of many investors in line with international best practices. ${ }^{55}$

\section{Companies and Allied Matters Act Cap C 20 LFN 2004}

Provisions for regulating mergers and acquisitions was repealed in the CAMA and transferred to ISA No. 45 of 1999 and subsequently ISA No. 272007 upon the repeal of ISA 1999. CAMA however still provides for incorporation of companies and memorandum and articles of association and the certification by the Corporate Affairs Commission for mergers and acquisitions purposes. Therefore, it is still relevant. ${ }^{56}$

\footnotetext{
${ }^{50}$ Dimgba, N. (2009)" Merger Control by Security and Exchange Commission: A Comparative Analysis of Investment and Securities Act 1999 and 2007" available at https://www.google.com.ng/amp/s/guardian.commssion-a-comparativeanalysis-of-investments-and-securities-act-1999-and-2007/anp visited 07/07/2017

${ }^{51} \mathrm{lbid}$

52 Ibid

${ }^{53}$ Section 128 ISA

54 Ibid

${ }^{55}$ Idigbe, T. opCit at P. 15

${ }^{56}$ Ogwu, D. opCit at P. $14-15$
} 


\section{The Banking and Other Financial Institutions Act (BOFIA) Cap B 3 LFN 2004}

The BOFIA empowers the Central Bank of Nigeria to sanction any merger taking place in the banking sector even the Securities and Exchange Commission which happens to be the apex regulatory authority requires a letter of no objection from the Central Bank of Nigeria before it can process any bank mergers. ${ }^{57}$ Based on the foregoing, the consent of the Governor of Central Bank of Nigeria must first be obtained before any bank will amalgamate or merge with any other person ${ }^{58}$

\section{Insurance Act Cap 118 LFN 2004}

The insurance act 2003 provides that for any merger and acquisition to take place in the insurance sector, the approval of the National Insurance Commission (NAICOM) and sanction of the court must first be obtained before companies can "amalgamate". ${ }^{59}$ The NAICOM Act also provides that the Commission may, before granting approval call for such statements, documents, and other information as shall enable it to reach a decision on the matter. ${ }^{60}$

Merging or acquiring firms are required to make newspaper publication in at least five national newspapers as well as serve same on the Commission or the court. The application to court or the Commission should contain the nature of amalgamation, transfer or acquisition. ${ }^{61}$ The NAICOM Act also provides that certified copies of draft agreement in respect to the proposed merger or acquisition, auditor's report in respect to the insurance company, actuarial report in respect to the insurance company is to be kept for inspection by members and policy holders at the principal and branch offices of the affected insurance company. ${ }^{62}$

The inspection for those concerned will last for a period of 21 days. ${ }^{63}$ Upon the completion of 21 days inspection process, the merger or acquisition may either be sanctioned by the court or the Commission if there is sufficient proof of no objection by the policy holders. ${ }^{64}$ The test for sufficient objection is established when it is established before the court or the Commission that not less than one fifth of the total number of policy holders object to the merger or acquisition. ${ }^{65}$

The approval of a merger or an acquisition by the Commission or the court does not amount to policy holders abandoning their claim which they had against the original insurer. ${ }^{66}$ A policy holder could nevertheless voluntarily decide to abandon his claim, which entitles him to claim the premium left on the remaining unexpired risk or to the mathematical reserve in the case of a life assurance. ${ }^{67}$

\section{Asset Management Corporation of Nigeria Act}

The Asset Management Corporation of Nigeria Act empowers the Corporation to among other things acquire the

\footnotetext{
${ }^{57}$ Ibid

${ }^{58}$ Section 7 (1) (iii)

${ }^{59}$ Section 30 (1) (a) and(b) NAICOM Act.

${ }^{60}$ Section 30 (2) NAICOM Act

${ }^{61}$ Section 30 (4) NAICOM Act.

62 section 30(5) NAICOM Act

${ }^{63}$ Section 30 (6) NAICOM Act

${ }^{64}$ Section 30 (7) NAICOM Act

${ }^{65}$ Section 30 (8) NAICOM Act

${ }^{66}$ Section 30 (9) NAICOM Act

${ }^{67}$ Section 30 (10) NAICOM Act 
assets of eligible banks and efficiently manage and dispose same in accordance with the provisions of the AMCON Act. ${ }^{68}$ A financial entity that is competent and willing to dispose its eligible bank assets to the Asset Management Corporation of Nigeria needs to make an application to the Corporation followed by a disclosure of information relating to warrantees, representations and indemnities which will guide the corporation on what value it is to place on the eligible bank assets. And finally the credit facility, documentation books together with records kept in connection to the eligible bank assets, must be provided for the purposes of inspection to the corporation. ${ }^{69}$

Upon the satisfaction of these requirements, the Corporation is still not bound to purchase eligible bank assets. Nevertheless, the Corporation might decide to acquire eligible bank assets upon a request from the Nigerian Deposit Insurance Corporation in consultation with the Central Bank of Nigeria. ${ }^{70}$ In the event the Corporation decides to acquire the assets of an eligible bank, then such bank shall submit to the Corporation all the necessary documents in respect to the acquired property and execute same. ${ }^{71}$

Purchase and indemnity agreement will be entered into between the Corporation and the bank whose eligible asset is been acquired by the corporation. This is to help the Corporation mitigate it losses in the event a security given by an acquired financial institution turns out to be worthless. ${ }^{72}$

\section{The Electric Power Sector Reform Act 2005}

Requires notification of approval to be given to the Nigerian Electricity Commission before an acquisition or amalgamation can take place in the electric power sector. As the enabling Act clearly requires that any licensee who intends to acquire interest from any firm that is in the business of electricity generation, transmission, system operation, distribution or trading other than as provided for in section 65 (2), section 67(2) and 68 of the Act has to notify the Commission. $^{73}$

\section{Nigerian Communications Commissions Act}

All mergers, acquisitions and joint ventures involving telecommunications companies incorporated in Nigeria are regulated by the Nigerian Communications Commissions (NCC). Pursuant to the NCC Act the transfer of shareholding above $10 \%$ between any companies operating in the telecommunication sector can only be materialized through the approval of the Commission. ${ }^{74}$ The Nigerian Competition Practices regulations 2007 made pursuant to the NCC Act 2003 requires a licensee to obtain prior approval of the Commission in respect of a direct or indirect transfer of acquisition of any individual licensee previously granted by the NCC. The regulation also empowers the Commission to prevent any transaction or acquisition that will prevent or lessen competition in the telecommunication industry.

\section{CONCLUSIONS}

Flowing from the above discussions, this paper has discovered from the research made so far that the lack of

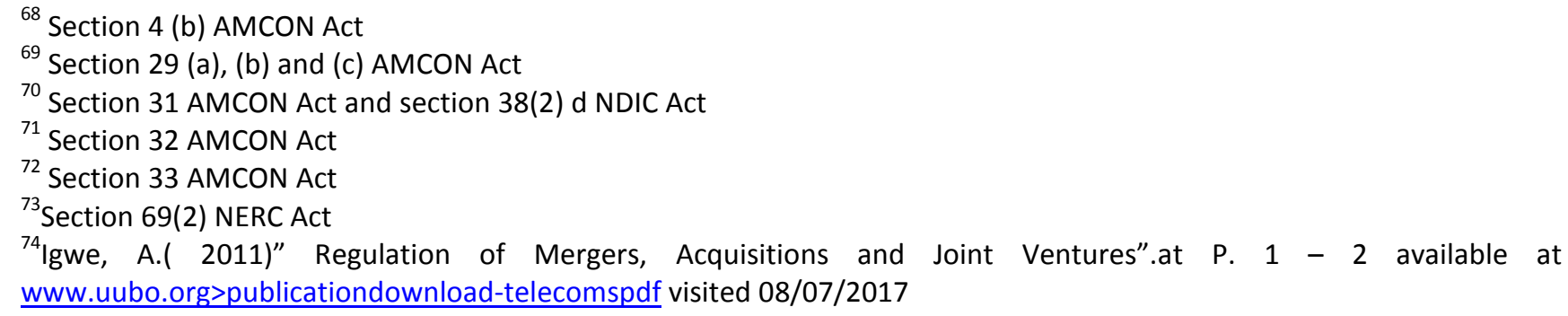


notification of trade unions of the merging entities or their representatives in the case of a large merger under the ISA could take most workers unaware and may possibly lead to protest which might hamper the merger deal due to fear of possible job losses that go with mergers and acquisitions generally. There is also failure to adequately intimate shareholders on mergers and acquisitions as majority of shareholders in practice only hear of the restructuring process in the media.

There are also governance challenges as to who will be at the helm of affairs when the merger or acquisition is eventually consummated. Lack of common vision on the part of merging entities has led to the collapse of most merger and acquisition transactions due to the fact that most companies only go into corporate restructuring such as mergers and acquisitions to survive economic downturn or meet the regulatory requirements for recapitalization without considering survival and efficiency strategies after the merger.

The regulatory bodies have also failed to prevent monopolistic practices that will substantially restrain competition. For instance, the acquisition of Visafone, the only surviving Code Division Multiple Access (CDMA) networks in Nigeria's telecommunications industries and the acquisition of Chi limited by Coca-Cola Company in 2016, has further led to monopoly rather than promoting healthy competition.

In light of the foregoing, this paper humbly suggest that government should create enabling environment for businesses to thrive by giving incentives or bailout to companies struggling to survive economic downturn instead of allowing them to be acquired by rival entities in order to prevent monopolistic tendencies, which is not good for the consumers nor the economy because monopoly only hampers economic growth and development as it holds consumers to ransom by leaving them with limited choices.

And since legislation is a continuous process, the ISA 2007 should be amended to include notification of trade unions or their representatives in the case of large merger just like in the case of intermediate mergers in order to protect the image of interested workers, who are the back bone of any organization in a merger or acquisition process. Regulatory authorities should also ensure that a good number of shareholders are carried along and not taken by surprise in order to prevent merger and acquisition transactions from being a business of the few. 
